\title{
The Origins of Public Prosecution at Common Law *
}

\author{
by JOHN H. LANGBEIN **
}

However fundamental he may appear to us, the public prosecutor was an historical latecomer. Judge and jury we can trace back to the high Middle Ages. But the prosecutor became a regular figure of Anglo-American criminal procedure only in Tudor times. Further, his appearance then has not been noticed in our historical literature, an especially remarkable omission when we discover that the prosecutorial office was originally lodged with a much-studied institution, the English magistracy. Ever since Maitland coined his famous phrase, that under the Tudors and Stuarts the justices of the peace became the "rulers of the county," they have attracted a substantial scholarship. Nevertheless, this major aspect of the work of the magistracy has remained unknown. The present article documents and accounts for the development by which the justices of the peace became the ordinary public prosecutors in cases of serious crime.

\section{The Medieval Background}

The public prosecutor in Anglo-American criminal procedure performs two primary functions. One is investigatorial-evidence gathering-and this has no firm border with the higher levels of the policing function. The other is the forensic prosecutorial rolepresenting the evidence to the trier (incident to which has developed the power to decide whether to prosecute). If the prosecutorial office to which the justices of the peace acceded was a creation of the sixteenth century, crime itself was no novelty of those years.

* ${ }^{\circ}$ Copyright 1973 by the President and Fellows of Harvard College. This article was presented in an earlier version as a paper at the 1972 meeting of the American Society for Legal History, Williamsburg. Certain portions will appear in the author's forthcoming book, Prosecuting Crime in the Renaissance: England, Germany, France. A grant in aid of the research was given by the National Endowment for the Humanities.

* * Professor of Law, University of Chicago Law School.

1. F. W. Maitland, Justice and Police, p. 80 (1885). 
How, then, had the English managed throughout the Middle Ages to dispense with the figure of the public prosecutor?

The public prosecutor appeared in consequence of the fundamental change in the structure of jury trial which took place in late medieval times. The Angevin system of self-informing juries had required no outside officer to investigate crime and to inform the jurors of the evidence. Jurors "were men chosen as being likely to be already informed," 2 the vicinage requirement, the rule that jurors be drawn from the neighborhood where the crime had been committed, was meant to produce jurors who might be witnesses as well as triers. ${ }^{3}$ Denunciation (to the jury of accusation) and proof of guilt (to the jury of trial) operated informally, that is, out of court and in advance of the court's sitting. In the thirteenth century "it is the duty of the jurors, so soon as they have been summoned, to make inquiries about the facts of which they will have to speak when they come before the court. They must collect testimony; they must weigh it and state the net result in a verdict."4 Medieval juries came to court more to speak than to listen.

The Angevin system of self-informing juries was breaking down in the late Middle Ages. This transformation of the active medieval juries into passive courtroom triers is among the greatest mysteries of English legal history, still no better understood than when Thayer wrote. ${ }^{5}$ As late as Fortescue (1460s) it was being boasted that the English jury merged witnesses and triers. On the other hand, Thayer noticed that a separation of witnesses and jurors could be found even in the early thirteenth century in cases disputing the genuineness of deeds, ${ }^{6}$ and a similar distinction seems to have been taken in some felony trials of the fourteenth and fifteenth centuries. ${ }^{7}$ Probably in the later fifteenth century, but

2. James B. Thayer, A Preliminary Treatise on Evidence at the Common Law, p. 90 (1898).

3. Thayer, op. cit. supra, note 2, p. 91.

4. Frederick Pollock \& F. W. Maitland, The History of English Law, v. 2, pp. 624-25 (2d ed., 1898) (foothote omitted). As late as 1427 it was provided by statute of $6 \mathrm{Hen}$. VI c. 2 "that in certain [civil] cases the sheriffs must furnish the parties with the jury's names six days before the session, if they ask for it, since (it is recited as a grievance) defendants heretofore could not know who the jury were, 'so as to inform them of their right and title before the day of the session,' . .." Thayer, op. cit. supra, note 2, p. 92 . Compare the position by 1624 as illustrated in the case of Trat's Murder, discussed infra, where the assize judge altered the composition of the Somerset grand jury to maximize the number of jurymen unfamiliar with the parties.

5. Thayer, op. cit. supra, note 2, pp. 130-36.

6. Thayer, op. cit. supra, note 2, p. 97.

7. Thayer, op. cit. supra, note 2, p. 124. 
certainly by the sixteenth, it had become expectable that jurors would be ignorant of the crimes they denounced and determined. ${ }^{x}$

We cannot seriously hope to identify the cause of a phenomenon whose internal development and timing we so little understand. Yet this much can be said with confidence: the medieval system of self-informing juries could not have survived into modern times. It presupposed a static populace and forms of communal social organization which were dissolving. Be that as it may, what matters for present purposes is not the cause but the consequence: the juries were ceasing to be self-informing. If the jury system were not to perish in England as it already had on the Continent, some other agency would have to come forward to assume the lapsed function. As. the jurors became bare lay judges, it became essential that outsiders undertake for the jurors the job we now call the prosecutor's.

\section{The Lawyer-Prosecutor?}

What are the origins of the office of the public prosecutor at common law? That question has not been much asked. Lawyers have generally assumed that the modern system of lawyer-prosecutors goes back to some sort of antiquity. In the American system the state's chief lawyer in the jurisdiction, the attorney general, is nominally responsible for prosecuting crime, aided by however many district attorneys and their hirelings. The surmise would be that such arrangements extend back at least to the Renaissance. And indeed, in the famous, occasionally infamous cases reported in the State Trials series, the law officers of the crown did regularly prosecute. It should suffice to mention only the most celebrated, the "shameful, unworthy, never to be forgotten"9 prosecution of Sir Walter Raleigh by Attorney General Sir Edward Coke in 1603. ${ }^{10}$

Raleigh's Case and the other State Trials of these years can, however, be misleading precedents when the concern is to understand the criminal procedure which was ordinarily used in cases of serious crime. The State Trials were extraordinary cases, touching the interests of the political authorities. They were in several

8. The Statute of Pirates, 27 Hen. VIII c. 4 (1535-36), 28 Hen. VIII c. 15 (1536), provided for jury trial in England for offenses committed on the high seas thousands of miles from the jurymen. See Thayer, op. cit. supra, note 2, p. $135 \mathrm{n}$. 1. Sir Thomas Smith's account (1565) of an ordinary criminal trial is quite unambiguous: witnesses testify before passive jurors. T. Smith, De Republica Anglorum, pp 78-81 (1583).

9. Catherine D. Bowen, The Lion and the Throne: The Life and Times of Sir Edward Coke (1552-1634), pp. 195-96 (1957); compare J. F. Stephen, A History of the Criminal Law of England, v. 1, p. 333 (1883).

10. 2 St. Tr. 1 (1603). 
respects the subject of special procedures not followed in cases of ordinary felony. To be sure, the procedures were not wholly dissimilar. Legislation had established in the middle of the fourteenth century the principle that capital cases were outside the trial jurisdiction of the Council. Only courts constituted by common law writ could deliver accused traitors and felons. It followed that no man needed to stand trial for his life unless he had first been indicted by a jury of accusation. ${ }^{11} \mathrm{His}$ right to a jury trial of guilt or innocence was likewise assured. But within common law criminal procedure, there were often significant differences between the State Trials and ordinary criminal cases. For the State Trials the judges were handpicked. They sat under special commissions of oyer and terminer-in London, under the eyes of the political authorities. By contrast, ordinary felony was tried locally, usually before royal judges on their regular assize circuits. In most State Trials the juries were also handpicked for the particular case, and they heard only that case. In ordinary cases the jurors were assembled by the sheriff for both the criminal and civil work of the assizes. Once impanelled, a criminal trial jury could hear the evidence in six or seven unrelated cases before retiring to formulate verdicts in all.

Most important of the procedural differences was that lawyers were typically not involved in the prosecution or defense in cases of ordinary felony. It is well known that the accused was regularly denied defense counsel in all trials of the period, political or not. ${ }^{12}$ What has not been recognized is that there was usually no prosecuting counsel either. Here the State Trials have misled us. We see Lord Coke prosecuting in Raleigh's Case, and we assume that some lesser light of the bar must have been doing the same job out in the countryside in less spectacular cases. That assumption is in fact wrong. In the few contemporary sources which do purport to describe ordinary criminal trials, for example Sir Thomas Smith's account (1565), there is no prosecuting counsel. ${ }^{13}$ We have not marked this point in our historical literature. The oversight is certainly understandable. Lawyers incline to project modern practice backwards unless there is clear contradiction. In part because there are no law reports from the ordinary criminal process of these years, we have seldom realized how exceptional ${ }^{14}$ the State Trials

11. William Holdsworth, A History of English Law, v. 1, pp. 486-88 (1956 ed.).

12. Holdsworth, op. cit. supra, note 11, v. 5, p. 192.

13. Smith, op cit. supra, note 8, pp. 75-84.

14. Exceptional not only in selection, being political cases, but also in preparation: the reporters were seldom neutral, the reports seldom contemporaneous. See G. Kitson Clark, The Critical Historian, p. 92 ff (1967). 
were. Actually, the absence of law reports for the criminal process when they do exist for contemporary civil litigation is itself telling. Law reports are lawyers' literature; they do not develop where lawyers have no role.

Once we are alert to the absence of the lawyer-prosecutor, we have little difficulty explaining it. The principal job of modern prosecuting counsel is to manipulate the rules of evidence at trial, and those rules were nonexistent through the sixteenth and most of the seventeenth centuries. ${ }^{15}$ The law of evidence is the law of jury control. It regulates what the jury can be told at the trial. But that presupposes the modern format of jury trial which was only just coming into currency in the sixteenth century: a courtroom instructional proceeding held for the benefit of a passive and ignorant panel of lay judges. The other important responsibility of prosecuting counsel in modern law is the operation of complex pretrial and trial procedural rules - the making of timely motions to suppress and the like. These rules, too, are comparatively recent. Criminal trial was still a fluid form in Sir Thomas Smith's day. He depicted a running "altercation" 16 between accused and accusers, and in this respect the State Trials are quite in accord.17 Moreover, many of the modern procedural intricacies are derivative to the law of evidence. Finally, because the possibilities for appellate review were extremely restricted, there was no effective mode of enforcing procedural "rights." The writ of error lay only for technical defects, defects of record, and two practices of the time made it all but certain that such defects would not be recognized. One was the rule forbidding defense counsel in most cases. The other was the practice of withholding from the accused any copy of the indictment, the significant item of record. ${ }^{18}$

\section{The Marian Statutes}

The juries were becoming passive. It was becoming essential that outsiders come forward to inform them. That responsibility was not being delegated to lawyer-prosecutors, apart from the rare State Trials. What was to be done?

For a very long time, really into the nineteenth century, the English relied upon a predominant, although not exclusive, component of private prosecution. The aggrieved citizen could inform the

15. This is not a novel point. See, e.g., Wallace Notestein, A History of Witchcraft in England, p. 44 (1911); Stephen, op. cit. supra, note 9, v. 1, p. 500 .

16. Smith, op. cit. supra, note 8, p. 80 .

17. E. g., Throckmorton, 1 St. Tr. 869 (1554).

18. See Stephen, op. cit. supra, note 9, v. 1, pp. 398-99. 
juries in court as in medieval times he had informed them out of court. We know from Sir Thomas Smith's account (1565) that the citizen volunteer was expected in the sixteenth-century criminal trial. The proclamation of the crier after the impanelling of the trial jury was more than ceremony: "If any can give evidence, or can saie any thing against the prisoner, let him come nowe, for he standeth upon his deliverance."19 The assize judge who was conducting the trial exercised a general superintendance over those who responded to the call, but witness and prosecutor were one. This citizen prosecutor was neither a lawyer nor an officer of the state. ${ }^{20}$ In modern American practice, where the public prosecutor has developed a monopoly over the instigation and conduct of criminal litigation, this citizen figure lives on as the complaining witness.

The obvious drawback to any system of gratuitous citizen prosecution is that it is unreliable. There will be cases where there are no aggrieved citizens who survive to prosecute, and others where the aggrieved citizens will decline to prosecute, or be inept at it. Because the public interest in law enforcement cannot allow such gaps, the English had to admit an official element into their system of citizen prosecution. The major steps in this direction were taken under Mary in 1554-1555 in two statutes which, almost imperceptibly, raised up the justices of the peace (JPs) as the public prosecutors for felony in England.

By way of background to the Marian statutes, it will be useful to recall a few generalities about the JPs. "They were in truth the Tudor 'men of all work.'" 21 They were for the most part leading local gentry, ${ }^{22}$ appointed by royal commission for each county and certain cities. The JPs originated in the fourteenth century as law enforcers, "keepers of the peace," foremost among whose duties was the arrest of vagabonds and rioters. By mid-century the "keepers" were "justices": sitting collectively in their quarterly sessions they comprised a law court for criminal matters. In the

19. Smith, op. cit. supra, note 8, p. 79 .

20. In England where official prosecution is in form limited to the handful of cases brought by the Director of Public Prosecutions, private prosecution continues in theory to be the norm: "When 'the police' prosecute, the correct analysis is that some individual has instituted proceedings, and the fact that this individual is a police officer does not alter the nature of the prosecution." R. M. Jackson, The Machinery of Justice in England, p. 155 (6th ed., 1972).

21. John P. Dawson, A History of Lay Judges, p. 139 (1960), quoting Holdsworth, op. cit. supra, note 11, v. 4, p. 137.

22. On the composition of the magistracy see J. H. Gleason, The Justices of the Peace in England: 1558 to 1640 (1969). 
fifteenth century the JPs' criminal trial jurisdiction was very extensive. Felons were routinely indicted, convicted and executed at sessions of the peace. ${ }^{23}$ By the mid-sixteenth century, however, it was rare for the JPs to try felons. The assize system had been revitalized, and felony cases were generally being held for trial before the royal judges on their periodic circuits. But the JPs continued to exercise their trial jurisdiction over lesser crime, the standard misdemeanors and the growing body of regulatory offenses. They had also become a licensing and administrative body. The line between law court and regulatory authority was (and to some extent still is) shadowy. Part of the reason the JPs drifted into what we think of as administrative business is that so much of it was then conducted in the forms of criminal litigation, with presenting or indicting juries being used to take orders in matters such as road repair and drainage.

Individual JPs also had important out-of-court responsibilities, including the power to bind over various troublemakers to keep the peace; to order the arrest of offenders; to commit accused persons to gaol until trial; and to release gaoled suspects on bail pending trial. The statutes and the commission of the peace which governed these out-of-court powers permitted a single JP to act in some matters, and in others required that two or more JPs join in the action. This work of the JPs harkens back to the office of the early "keepers of the peace" who rode forth to arrest vagabonds and break up riots. It was from this ancient side of their office that the Tudor JPs developed into public prosecutors for felony. The JPs had already in the late Middle Ages become ascendant over the constables, whose powers of spontaneous arrest were mostly limited to fresh pursuit. The JPs could order arrest on suspicion, and theirs was the power to order an accused committed to stand trial. Consequently, well before the Marian statutes the JPs were the officers to whom aggrieved citizens would make complaint of serious crime. In a series of more than 30 statutes from the late fourteenth through the middle sixteenth centuries, the JPs were empowered to examine witnesses and suspects incident to summary powers of conviction or accusation in various petty matters. A few sources from the early sixteenth century show that the JPs in at least some places had also taken to examining witnesses and suspects in cases of serious crime-conducting what we would call pretrial or preliminary examination. ${ }^{24}$.

23. Bertha H. Putnam, Introduction, Proceedings before the Justices of the Peace in the Fourteenth and Fifteenth Centuries, pp. cxii-cxvii (1938).

24. These sources are discussed in Chapter 4 of $\mathrm{my}$ forthcoming book, 
From a very early time (1360-1361) individual JPs had also been empowered by statute ${ }^{25}$ to grant bail under prescribed conditions to persons awaiting trial for some offenses including some felonies. An act of $1487^{26}$ required that a minimum of two JPs join in making the bailment, and it authorized the assize judges to impose fines upon JPs who bailed improperly. That procedure had revealed some imperfections, which is where we pick up the story of the Marian statutes of 1554-1555. The first statute, the Marian bail statute, ${ }^{27}$ was by its terms no more than a further regulation of the JPs' power to grant bail. The preamble complains that some unscrupulous JPs had been abusing their power to bail accused felons. A lone JP, conniving for whatever reason with an accused felon, might easily procure the required second signature from one of his fellow justices. The felon thereby bailed would turn fugitive. Then when the assize judges came to deliver the gaol, they not only could not try the felon, but also they had no adequate means to evaluate the legality or the reasonableness of the bailment. The Marian bail statute meant to remedy this collusion. It required that both JPs act simultaneously in granting bail-no more of the practice of one JP signing a colleague's stale bailment in order to spare him trouble at assizes. Further, the assize court was now to be given a proper basis for reviewing the propriety of defaulted bailments. The Marian act laid down a new procedure to be followed by the JPs before they released an accused felon on bail. The two justices were first to

take the examination of the said Prisoner and information of them that bring him, of the fact and circumstances thereof, and the same, or as much thereof as shall be material to prove the felony shall be put in writing before they make the . . . Bailment, which said examination together with the said Bailment the said Justices shall certify at the next general Gaol Delivery . . . .

The examination document would provide the judges at gaol delivery (assizes) a basis upon which to decide whether the JPs had acted properly in making bailment.

Quite promptly in 1555 the next Parliament enacted the curt and laconic Marian committal statute, ${ }^{28}$ which extended this pro-

Prosecuting Crime in the Renaissance: England, Germany, France (1974).

25. $34 \mathrm{Edw}$. III c. 1 (1360-61).

26. 3 Hen. VII c. 3 (1487).

27. $1 \& 2$ Phil. \& Mar. c. 13 (1554-55). (Throughout this article spelling is modernized in quotations from this and the second statute.)

28. 2 \& 3 Phil. \& Mar. c. 10 (1555). 
cedure of the Marian bail statute to cases in which bail was denied, that is, to cases in which the JP committed the accused felon to gaol to await trial. When the JPs commit rather than bail, the preamble says mysteriously, "examination of such Prisoner, and of such as shall bring him, is as necessary or rather more, than where such Prisoner is let to Bail . . . ." This "necessity," which the committal statute does not further explain, was remote from the purpose of the bail statute. The bail statute had been designed to provide the assize judges with an account of the evidence against the accused in order that they might have a basis for reviewing the propriety of the bailment in any case in which the accused had turned fugitive and the issue now was whether to discipline the bailing JPs. But when the accused was going to be gaoled, not bailed, there was no danger that he might not appear to stand trial. Why then the examination?

The examination procedure which was transposed from the bail statute to the committal statute contained an additional step, ${ }^{29}$ and it is the extra step which reveals to us the function of the committal statute. Not only was the examining JP 30 to question and transcribe the statements of the accused and the accusers and to certify the document to the trial court of gaol delivery (as under the bail statute), he was also

to bind all such by Recognizance or Obligation, as do declare anything material to prove the . . . Felony ... against such Prisoner . . . to appear at the next general Gaol Delivery . . . to give evidence against [him].

The examining JP was being formally instructed to gather evidence for trial and to bind witnesses. The Marian committal statute was employing the procedure of the bail statute to a radically different end. The bail statute intended to deter or to detect and punish a corrupt practice among a relative handful of JPs. The committal statute turned the pretrial investigation into a device for the production of prosecution evidence at trial in every case of felony in the realm.

The committal statute, which had been provoked by the passage of the bail statute and had consciously appropriated its proce-

29. Suggested by a provision of the bail statute (but not relating to bail), governing investigations conducted by both JPs and coroners. This section of the bail statute and its connection to the Marian committal statute are discussed in my forthcoming book, op. cit. supra, note 24 , ch. 1.

30. A single JP could commit an accused to gaol, whereas it required two JPs to bail him. 
dure ${ }^{31}$ provided the means to remedy the more troublesome deficiencies of a system of merely gratuitous citizen prosecution. The committal statute regularized and reinforced the developed pattern of private prosecution. It transformed the role of the private accuser from option to obligation. The JPs would bind over the accuser to prosecute. On pain of forfeiting his bond, the accuser would be obliged to appear at gaol delivery to give evidence before the assize judges and the two juries. The citizen who lost his taste for revenge between the crime and the trial, or who was intimidated, or who was loath to make a long journey to the county town for assizes-he would now be bound to attend and to give evidence.

It was not every accuser whom the committal statute directed the JPs to bind over, but only those who could "delcare anything material to prove the . . . Felony . . . ." The JPs were expressly empowered to separate the "material" witnesses from the others in a case where many accusers had come forward. But what of the reverse case - a covert crime which would require active investigation to identify the culprit and any witnesses? The statute does not by its terms direct that the JP do more than examine an accused and those who "bring" him. It is likely that the draftsman thought he was dealing with covert crime as well, but that because he tried to borrow the language of the previous year's bail statute as a shortcut, he accidentally omitted to articulate the active investigativeprosecutorial role he intended.32 The oversight caused no immediate difficulty, no rush to revise the language to make the active role more explicit, because the mechanics of examination were adequately set forth, and because the purpose revealed itself to contemporaries without better labelling. The investigating magistrate was not a figure wholly novel to the Marian statutes. The JPs. already had by statute lesser duties which acclimated them to the role of investigating magistrate; and indeed, there is some evidence that they actually assumed the role of investigating magistrate for felony in advance of the Marian statutes. ${ }^{33}$

The draftsman's intent is, in any event, a side issue. The decisive fact for present purposes is that the contemporary magistracy did understand that an active role was expected in difficult cases. Dalton's handbook (1618) for JPs notes: 34

And if after [committing the accused and binding over the "bringers"] the said Justice shall heare of any other persons that can informe any materiall thing against the prisoner (to

31. Op. cit. supra, note $24, \mathrm{ch} .3$.

32. Op. cit. supra, note 24 , chs. 1-2.

33. Op. cit. supra, note 24 , ch. 4.

34. Michael Dalton, The Countrey Justice, p. 262 (1618). 
prove the felony whereof he is suspected) the said Justice may grant out his Warrant for such persons to come before him, and may also take their Information, \&c. and may binde them to give in evidence against the prisoner: For every one shalbe admitted to give evidence for the King.

In this way the Marian scheme was making the JPs into back-up prosecutors. Private citizens, now bound by recognizance as required by the Marian statute, would continue to prosecute most cases. But when there were no private accusers, or when their evidence was not going to be sufficient, it was the JP who would investigate, bind witnesses, and appear at assizes to orchestrate prosecution. At the trial he could testify about his investigation, and he would sometimes undertake the further forensic role of interrogating the accused publicly before the jury. (The next section of this paper presents evidence from Elizabethan and Jacobean sources which shows the JPs engaged in such prosecutorial work.)

The most recent general history of the magistracy, 35 (like the first such book ${ }^{36}$ ) overlooks the Marian statutes completely, and hence, overlooks completely the prosecutorial role of the JPs. If the Marian statutes have had such fundamental structural importance, establishing the office of the public prosecutor in ordinary common law criminal procedure, why have historians misappreciated it? Several factors have conspired to mislead us. The State Trials have lulled us into assuming that if any officer was prosecuting, he must have been a law officer. Further, the awkward derivative draftsmanship of the Marian committal statute has helped to conceal the purpose and function of the act. And because the JP was an interstitial prosecutor, filling the gaps in a system of citizen prosecution, his hand has often been hard to detect, especially in the absence of law reports. By the time for which the law reports are ample, the nineteenth century, the magistrate's role had altered greatly. He still conducted something called a pretrial investigation, but it was the judicialized preliminary committal hearing; $; 7$ professional police were superseding the JP in the field, and barristers who could contend with the law of evidence were displacing him from the prosecutor's table at assizes. Finally, we have been misled by Holdsworth, who made of the Marian statutes another chapter in his dubious thesis that English criminal procedure under the Tudors was

35. Esther Moir, The Justice of the Peace (1969).

36. Charles A. Beard, The Office of Justice of the Peace in England in Its Origin and Development (1904).

37. See Stephen, op. cit. supra, note 9 , v. 1, p. 228 , and statutes there cited. 
undergoing a "reception" of Continental inquisitorial ideas. 38 By deeming the Marian magistrate's examination a foreign graft, the reception thesis obscured both its context and its function within the changing common law criminal procedure.

\section{The Prosecuting JP in Action}

The deficiencies of the surviving historical sources from the early modern criminal process, especially the lack of ordinary law reports, have tended to conceal the prosecutorial role of the JP. Nevertheless, once we are alerted to him, we can see the prosecuting JP in action in a goodly range of Tudor-Stuart sources. A few law reports from ordinary criminal trials from Restoration times appear in the State Trials series, and in some of these the prosecuting JP cuts a very clear figure. Stephen observed of these and other cases that "the justice who had got up the case was the principal witness against the prisoner, and detailed at length the steps which he had taken to apprehend him."39 But the earliest of Stephen's cases is more than a century after the Marian statutes. Ideally, we would like to glimpse the prosecuting JP in the formative days of his office.

Examination documents and recognizances binding over witnesses to prosecute which were submitted by the JPs as prescribed by the Marian statutes can be found in the assize files in the central archives, some dated within a few years of the Marian statutes. Indeed, there are similar documents among local record collections which predate the statutes by as much as 35 years $^{41}$ (a fact which strongly supports the view that prior informal practice among the magistrates suggested the Marian procedure). On the other hand, these records are patchy until well into the seventeenth century. They are also ambiguous for present purposes, because it is difficult to infer from the examination documents alone how they related to the rest of the criminal procedure. We should like, therefore, to supplement the fund of examination documents with narrative authority in order to make out the contention of this paper, that it was a prosecutorial and not some other function which the JPs acquired under the Marian statutes.

Sir Thomas Smith's famous tract, De Republica Anglorum (1565), written within a decade of the Marian legislation, provides particularly early and helpful authority. Smith discusses judicial procedure and the activities of the JPs as part of his larger commentary on the workings of English government. He recounts the

38. See Holdsworth, op. cit. supra, note 11, v. 4, pp. 528-29.

39. Stephen, op. cit. supra, note 9 , v. 1, pp. 222-23.

40. See text at note 24 supra. 
taking of examination in two passages. In one of them he explains the control exercised by the JPs over the constables, a control he instances by showing a JP actively instigating examination and committal of an accused. ${ }^{41}$ Elsewhere, supposing a robber caught in the act and brought before the JP, Smith shows us how the JP used the pretrial examination to build the case against the accused: ${ }^{42}$

So soone as any is brought to the Justices of peace by this hue or crie, by the Constable or anie other who doth pursue the malefactor, he doeth examine the malefactor, and writeth the examination and his confession: then he doth binde the partie that is robbed or 'him that sueth, and the Constable, and so manie as can give evidence against the malefactor to be at the next sessions of gaole deliverie to give their evidence for the Queene. He bindeth them in recognisance of [ten, twenty, thirty, forty or a hundred pounds] according to his discretion, and the qualitie of the crime: which certified under his hande, is levied upon the recognizance if they faile of being there.

Smith's description is amplified by the JP manuals of Lambarde (1582) and his followers, which provide forms of examination and recognizance as well as advice on sifting evidence. Because the Marian committal statute "requireth that the Justice of peace should in taking the examination, make choise of suche things as bee material to prove the offence," Lambarde includes a discussion of "what actes those bee, that doe amount to Manslaughter or Felony: . . ."43 Beginning with the 1588 edition, Lambarde supplies an elaborate amateur detective's guide to "the pointes that may ingender Suspition . . . ", 44 indicia bearing on the suspect's motive, opportunity and capacity to commit the crime.

Sir. Thomas Smith continues his account to the trial itself, where it stops tantalizingly short of describing the prosecuting JP in his forensic role. The accusing witnesses who have been bound over do in the usual case appear, and are led in their testimony by the presiding assize judge. ${ }^{45}$ But suppose the witnesses do not appear to prosecute? "[T]hen the Judge asketh who sent [the accused] to prison, who is commonly one of the Justices of peace. He if he be there delivereth up the examination which he tooke of

41. Smith, op. cit. supra, note 8, pp. 74-75.

42. Smith, op. cit. supra, note 8, p. 72 .

43. William Lambard [e], Eirenarcha: or Of the Office of the Justice of Peace, p. 211 (1581 [o.s.] ).

44. Lambarde, op. cit. supra, note 43, 1588 ed., p. 218.

45. Smith, op. cit. supra, note 8, p. 80 . 
him," together with the names of the defaulting witnesses (whose bonds the court orders to be paid). But "although the malefactor hath confessed the crime to the Justice of the peace, . . . [the jury] will acquite the prisoner . . . Howbeit this doth seldome chaunce, except it be in small matters, and where the Justices [sic] of peace, who sent the prisoner to the gaole, is away." 46 For our purposes Smith stops one sentence short: he does not complete his thought and tell his readers what would have been different in that case if the examining JP had been present in court. I suggest that the difference was that the JP's own testimony could persuade a jury which would otherwise acquit, so that already in the $1560 \mathrm{~s}$ as in the next century in cases where citizen prosecutors failed it was "the justice who had got up the case [who] was the principal witness against the prisoner, and detailed at length the steps which he had taken to apprehend him." 47

For Jacobean times the figure of the JP as courtroom prosecutor is at least occasionally evidenced in the peculiar "chap-books" or lay pamphlets, which describe the investigation of particular crimes. These pamphlets were written by nonlawyers for sale to the general public. The authors are generally anonymous or identified by initials only. In the era before newspapers the chap-books held the place of the sensation-mongering element of the modern press. They were almost all published in London and offered for sale there, even when the events being reported occurred at a distance. The crimes narrated break down into three somewhat overlapping categories, each having a manifest appeal to sensation-seeking readers: (1) especially gruesome murders, often involving dismemberment or the burning of the corpse; (2) crimes of witchcraft (easily the most numerous); and (3) crimes of betrayal against a spouse or a master. Persons of gentle status appear as culprits and victims in a surprising proportion of the pamphlets, especially in non-witchcraft cases; perhaps it excited the readership when felony overflowed its normal course within the lower orders. Not infrequently the pamphlets feature crude drawings on the title page, for example, the witch with her demons, the dismembered corpse, or the hanged felons dangling in their nooses. Timeliness aids sensation; the pamphlets appeared quite rapidly after the events-occasionally even before execution of sentence. The risk of being scooped by a competitor may also have pressured the entrepreneurs of the trade into producing their pamphlets promptly after the events. Their timeliness is a factor which enhances the reliability of the chapbooks as a legal historical source. These crimes were not legends

46. Smith, op. cit. supra, note 8, pp. 79-80.

47. Stephen, op. cit. supra, note 9, v. 1, pp. 222-23. 
embellished over long years of retelling. More important for present purposes, the work of the JPs is a relatively peripheral aspect of the chap-book scenarios. What really interested the author and his audience, and occasionally did produce exaggeration, was the gore of the crime and the drama of the culprit's downfall. The witchcraft pamphlets, the only ones to have attracted much scholarly attention, have been regularly verified when checked against surviving legal records. ${ }^{4 x}$

The most useful for present purposes of the chap-book cases is among the least credible. Dells' Case (1606) ${ }^{49}$ involves the slaying of a three-year-old boy by an elderly woman, Annis Dell, and her grown son, both of whom were convicted and executed for the murder. There has been considerable exaggeration (if indeed the whole tale is not an outright fabrication). However, in our context a hypothetical magistrate's investigation is nearly as good as a real one, since the hypothetical still typifies the prosecutorial practice of the time as the author understood it. The victim's body was found in 1602 in a ditch near Hatfield, Hertfordshire, dressed in a fashionable coat. The coat was sent to various market towns in the area and was recognized by a tailor, who had seen the boy wearing it and remembered it because he had intended to copy the design. He had seen the boy being led into the Dells' inn together with a girl child who was perhaps a year older. "The newes of this comming to the eares of Sir Henry Butler and one other knight, being both Justices, and both dwelling neere to that place, a warrant was made, by vertue whereof, the said Mother Dell and her Sonne were brought before them both, and strictlye examined . . . ." They explained that the two children had been brought to the house by a traveling peddler and his wife, and that both children had departed again with the peddlers. "Upon this their confession, they were both bound over to appeare and answere at the next Assizes, the Justices hoping ere that time to finde out the actor or actors of that more then [sic] monstrous tragedy." New clues did not develop; "yet notwithstanding, they were still bound over from Sise to Sise, almoste for foure

48. A careful recent archive study concludes: "Comparison of indictments and pamphlet accounts [from Elizabethan Essex] supports the general accuracy of both sources. Although there is not always exact overlapping, since each source contains material not found in the other, when they are describing the same event there is little direct contradiction. When there is disagreement, it is on minor matters and supports the general impression of accuracy." A. D. J. Macfarlane, Witchcraft in Tudor and Stuart England, p. 85 (Harper ed., 1970) (footnote omitted). Cf. Notestein, op. cit. supra, note 15, p. 346.

49. Anon., The horrible Murther of a young Boy of three yeres of age, whose Sister had her tongue cut out ... (London 1606). 
yeares . . . ." Then in 1606 there reappeared the little girl whom the tailor had seen accompanying the murdered child to the Dell house. The Dells had abandoned her to die in a "sildome frequented" wood, having first cut out her. tongue. She got loose and supposedly went wandering and begging for four years, till one day she chanced to find herself again before the Dell house. This set her to crying, making "extraordinarie noyse" and pointing to the house. Her performance attracted a crowd, which was soon joined by the tailor. He recognized her, whereupon the neighbors hustled her, the tailor, and Annis Dell and her son "before Sir Henry Butler, who was the next Justice (and had examined [the Dells] divers times before concerning these Children) . . . ."When the constable told Butler what had just happened, "hee did with greate wisdome and discretion, examine them aparte, one from another." Both denied ever having seen the girl, although "the Taylor did still affyrme it to their faces, that that was the Girle which the Pedler and his wife led into their house long since with the boy." Butler ordered the Dells committed for trial. Then, some little while later by a "mightie miracle" the girl regained her power of speech. Those caring for her "led her againe to the knight before named [Butler, the JP], to whom they told what had happened." He questioned her and elicited all the detail of the murder of her brother and the maiming of herself (the peddler couple had previously robbed and murdered her parents, and had paid the Dells to take her brother and herself).

To conclude, the Sises being come; an Inditement was prefered against the mother and the sonne, to which inditement they pleaded not guiltie, and put themselves to the ordinarie triall. Whereupon the childe was brought before the Bench, and stood upon the Table betweene the Bench and the Jury. Where after that the foresaid knight had opened some part of this foule offence, the childe was asked diverse of the former questions: to which she answered as before. The taylor likewise was there, who tolde unto the Jurie what he had seene. Then the Jurie was willed to goe togither: but before they went, they did looke into the childes mouth, but could not see so much as the stumpe of a tongue therein. The Jurie staid not long before they returned with their verdite guiltie, whereupon they had sentence of death pronounced against them, and were both hanged at Hartfort, the fourth day of August. 1606.

It is hard to know how much of this story to disbelieve. The girl's sudden tongueless speech is incredible, as is her four years in the wilderness between ages four and eight. The tailor also looks some- 
what contrived.50 No matter how much of the scenario was invented, it is likely that the prosecutorial role of the JP in Dells' Case is a faithful typification. The author had every incentive to supply maximum verisimilitude to the lesser details of a plot which otherwise turned on a "mightie miracle" and such. The case is attractive for present purposes because it illustrates so clearly the way in which the investigating JP was led to take up a forensic role at trial. Butler "opened some part of this foule offence," that is, he made an opening statement to the jury. And because his star witness was a child who had to be guided in her testimony, he asked her "the former questions"- - he reenacted with her before the trial jury the material parts of the out-of-court examination which he had previously conducted.

Fortunately, another pamphlet of undoubted reliability also evidences the prosecuting JP in both his investigatorial and forensic roles: The wonderful discoverie of Elizabeth Sawyer a Witch, late of Edmonton, her conviction and condemnation and Death. . . . Written by Henry Goodcole Minister of the Word of God, and her continuall Visiter in the Gaole of Newgate (London 1621)." The pamphlet tells how Elizabeth's doings fell under the suspicious "eye of Mr. Arthur Robinson, a worthy Justice of Peace, who dweleth at Totnam [Tottenham] neere to her," and how he prosecuted her to her death. Robinson had long suspected her of witchcraft, as did her neighbors. He sprang into action after "seeing the death of Nursechildren and Cattell, strangely and suddenly to happen." Goodcole's narrative is based on the trial, which he observed. Elizabeth was indicted at the Old Bailey on three counts; she was convicted of one, murdering a neighbor, Agnes Ratcleife, by witch's curse. Agnes had struck a sow of Elizabeth's; Elizabeth "threatened Agnes Ratcleife, that it should be a deare blow unto her, which accordingly fell out, and suddenly; for that evening Agnes Ratcleife fell very sicke, and was extraordinarily vexed, and in a most strange manner in her sickness was tormented ...." Agnes lingered for four days, saying

50. There is another pamphlet version of this case, Anon., The most cruell and bloody Murther committed by an Inkeepers Wife, called Annis Dell . . . (London 1606). The tailor is barely mentioned and Butler's investigations go undescribed. Notestein was interested in this pamphlet because an account of a witchcraft case is appended to it. He was unable to confirm the events. Notestein, op. cit. supra, note 15, p. 356.

51. On the reliability of the pamphlet see Notestein, op. cit. supra, note 15, p. 359. Signed pamphlets of the genre are rare. Goodcole also produced a later one: Heavens speedie Hue and Cry sent after Lust and Murther.(London 1635) (a pair of robbers are captured, confess, and are executed). 
to her husband that Elizabeth was occasioning her death. At the trial the husband and the neighbors testified (presumably having been bound over by Robinson to appear). But the jury remained in doubt. "The Foreman of the Jury asked Master Heneage Finch": Recorder [the presiding judge], his direction and advice, to whom hee Christianlike thus replyed, namely, Doe in it as God shall put in your hearts." The JP, Robinson, must have taken the foreman's question as a sign that the jury was at least wavering. He "had often \& divers times, upon the complaints of the neighbours against this Elizabeth Sawyer, laboriously and carefully examined her . . . ." He had learned from some neighbors that Elizabeth "had a private and strange marke on her body, by which their suspition was confirmed against her, and hee sitting in the Court at that time of her triall, informed the Bench thereof, desiring the Bench to send for women to search her . . . ." Three women were appointed, and duly reported back to the court that they had found a witch's mark. ${ }^{33}$ This "gave some insight to the jury," which then convicted her of the murder, for which she was executed. Robinson's performance exemplifies again the prosecuting JP continuing on from the Marian pretrial investigation to the trial. When he saw his case faltering after his witnesses had testified, he jumped up to add new matter which carried the day.

The chap-books tend to portray the prosecuting JP solely in his investigatorial role, and this is as we should expect. The JP's forensic role was exceptional, and the procedural detail of the trial held no interest for these lay authors and readers. The few Elizabethan pamphlets, which deal mostly with witchcraft, are not so revealing

52. The father of Lord Chancellor Nottingham. The Recorder of London was always a leading lawyer who often advanced to the common law bench. He sat under his regular commission of oyer and terminer in a case like Sawyer. But the Recorder was also a JP. Perhaps it was in that capacity that Finch's predecessor, Sir Henry Montagu, conducted the extensive pretrial investigations in the homicide case of Elizabeth Abbot (1608), which was tried before Sir Edward Coke. " $[\mathrm{M}]$ y Lord Chiefe Justice, rising from his seate [at the conclusion of the trial], gave Sir Henry Mountegue a worthy commendations [sic] for his industry and labor in this case, protesting that since he was acquainted in ye state of such business, he never hears examinations better gathered, a course better shifted, nor a murther stronglier discovered . . . ." Anon., The apprehension, arraignement, and execution of Elizabeth Abbot... (London 1608). Montagu's prosecutorial work cannot, of course, be cited in direct support of the thesis of this paper. He was the exceptional lawyer-prosecutor, closer to the model of the law officers of the crown than that of the country JP.

53. It is quite clear from the description in the pamphlet that what the women found upon Elizabeth's body was a hemorrhoid. 
about the work of the JPs (or about much else) as some of the later ones. They commonly string together pretrial examinations with little or no narrative, occasionally appending to the pretrial records some sketchy mention of trial and execution. ${ }^{54}$ One of that variety which does portray a determined JP's pretrial investigation is a pamphlet account of the Essex withcraft outbreak of 1582, believed written or at least instigated by the examining JP himself, Brian Darcey.5' That pamphlet purports to reprint Darcey's many examinations, from which it has been fairly observed that he "took particular pains in examining the suspects and his methods included much cajoling and bullying." 56 Toward the end of the century the pamphlets expand beyond witchcraft and become more coherent. $\overline{ }$ "

Elizabeth Caldwell (1604), ${ }^{5 \times}$ a well-born young woman recently married and living in the county of Chester, attempted with her paramour and a cohort of his to kill her husband by baking him some poison cakes. He survived, but a neighborhood child with whom he shared a cake did not.

Upon the death of this child, Elizabeth Caldwell was apprehended, and brought before three Justices of the peace; namely, Sir John Savage, Sir Thomas Aston, and maister Brooke of Norton, where before them she truly confessed all their practises and proceedings from the beginning, even till that day. Upon which confession, [the two accomplices] were apprehended, and brought before the same Justices, and examined as touching the murder, and they very stoutly denied all ....

54. E.g., Anon., A Detection of damnable driftes, practized by three witches arraigned at Chelmisforde in Essex . . . (London 1579).

55. W.W., A True and just Recorde of the Information, Examination and Confession of all the Witches taken at St. Oses in the countie of Essex (London 1582). "The pamphlet is merely a record of examinations. It is dedicated to Justice Darcy; and from slips, where the judge [JP] in describing his action breaks into the first person, it is evident that it was written by the judge himself." Notestein, op. cit. supra, note 15, p. 348.

56. Macfarlane, op. cit. supra, note 48, p. 85.

57. E.g., Anon., A briefe discourse of two most cruell and bloudie murthers, committed bothe in Worcestershire, and bothe happening unhappily in the yeare 1583 (London 1583); L.B., The Examination, confession and condemnation of Henry Robson, Fisherman of Rye, who poysoned his wife in the strangest maner that ever hitherto hath bin heard of (London 1598) (by introducing rat poison into her vagina).

58. Gilbert Dugdale, A True Discourse Of the practises of Elizabeth Caldwell. . . . Written by one then present as witnes, their owne Country-man, Gilbert Dugdale (London 1604). 
The trial is described only in the result: the paramour refused to plead at the assizes, in order to preserve his property from forfeiture, and was pressed to death. The other accomplice was convicted and executed, as was Elizabeth Caldwell.

Thomas Cash (1607):9 and a servant girl murdered Cash's first wife some 25 years before in Lincolnshire. Cash then jilted the servant girl and married someone else. Now on her deathbed in Shoreditch (London) the servant confessed the murder to her minister. He reported it to the high sheriff of Lincolnshire, who was then in London.

$[\mathrm{H}] \mathrm{e}$ immediately sent order down for the apprehending of this Thomas Cash: who being apprehended, was had before sir William Wray knight, one of the Kings Majesties Justices of the aforesaid countie, who being accompanied at the time when the prisoner was brought with one master Robert Turret, fell to examining of the prisoner concerning the fact, who presently confessed it before sir William Wray and the foresaid maister Robert Turret.

When the pamphleteer wrote, Cash was awaiting trial at the next assizes.

Numerous chap-books ${ }^{60}$ chronicle the investigating JPs in witchcraft cases. Arthur Bill $(1612)^{61}$ is a convenient case to mention because it shows the JPs investigating in a fashion well beyond the Marian statutory minimum of oral examination and transcription. Bill (and others of his family) were put by the JPs to "an experiment that (many thinke) never failes" known as swimming the witch. His limbs were tied and he was thrown into water. When he did not sink, his guilt was clarified. He was convicted at assizes and executed.

Trat's Murder (1624), ${ }^{62}$ the last of the Jacobean chap-book cases known to me, is perhaps the most interesting on account of its Sherlock Holmes properties. It portrays a dogged investigation by a pair of Somerset JPs. There is no reason to doubt the tale-the author, one C.W., purports to tell it "according to the best informa-

59. Two horrible and inhumane Murders done in Lincolneshire, by two Husbands upon their Wives ... (London 1607).

60. Extensively discussed in Notestein, op. cit. supra, note 15, where, however, no particular note is taken of the legal procedural significance of the activities of the JPs.

61. Anon, The Witches of Northamptonshire . . . who were all executed at Northampton the 22. of July last. 1612 (London 1612).

62. C.W., The crying Murther: Contayning the cruell and most horrible Butchery of Mr. Trat . . . (London 1624). 
tions he could receive from the Coroner, Jurours, and other worthy persons conscious of all these particulars . . . ." He dedicates the pamphlet to Chief Baron Tanfield, the assize judge, and to the Somerset JPs. Trat, the victim, described as a B.A. of Magdalen College,. Oxford, and a widower, was curate of the vicarage of Old Cleeve. His murder was engineered by Peter Smithwicke (sometimes Smethwicke), Junior, the son of a substantial landholder whose own complicity in the crime had not yet been determined when the pamphlet was written. Trat was about to purchase the vicarage from the absentee incumbent, who had acquired it from the Smithwicke family by marriage. The Smithwickes seem to have thought themselves entitled to its return, and wanted its "good annuall profit" back in the family. To prevent the sale Young Peter Smithwicke arranged for two or three of his servants to waylay Trat and kill him. They dismembered his body, boiled and salted it piecemeal, and buried the remains in Trat's home. Further to confuse detection, one of the culprits went riding off across the countryside on the day of the murder dressed in Trat's habit and stopping on occasion to identify himself as Trat. At one point the impersonator "admitted" that he was fleeing, having slain a strange Irishman with whom he fell to brawling in his house. After a fortnight the stench from Trat's house induced a search, where some headless remains of the body were found.

[The neighbors gave] notice unto Mr. Thomas Windham of St. Decoombes, unto Master Cusse of Creetch, Justices of Peace in the said County, who with Mr. John Westcombe of Haulse, Coroner for the King, came upon their first summons, and taking view of this strange and amazing object, they were much perplext .... [T] hey proceeded from thence unto examination of some of the neighbours in that Parish: the Intelligence of whose report might give their eyes some informing light in the mysterie of this businesse. Those examinates ma [d]e it known unto them, that in all likelihood it was Mr. Trat their olde Curate that was murthered, there being one of his fingers knowne by a secret marke unto them, and besides, there was a known quarrell betweene Mr. Smethwickes company and him . . . which gave some cause of suspition unto them, and that Alice Walker besides, servant unto olde M. Smethwicke, had before told some of these Informers, that if the Parson did not come home the sooner, his powdred Beefe would stinke before his comming. These presumptions drew her first of all unto question, and examination before the Justices, who were very sincere and carefull in the finding out of this murderous and Butcherly plot. She being tax'd, stoode 
upon the deniall, but there being great presumptions of her guiltinesse, she was committed unto prison.

Perhaps because of Alice's talk, the JPs were not deceived by reports of the impersonated fugitive Trat. Windham and Cusse searched the Smithwickes' premises, where they found property belonging to Mr. Trat, as well as some further pieces of the parson himself. One of the culprits, Andrew Baker, they caught there trying to dispose of "a pot of stinking blood." Another, Cyrill Austin, gave himself away by gossiping about the murder before it was generally known and by clumsily disposing of a bloody handkerchief when it was noticed upon him. The neighbors informed Cusse, the JP, who led an unsuccessful hue and cry to capture him. He was apprehended in Wiltshire, however, where he was examined by another JP and refused to confess. (He was returned to Somerset for trial and convicted with the others.) Young Smithwicke, the apparent mastermind, was convicted on evidence not described, the gist of which was that he had once threatened to cut Trat to pieces and that he had been overly conspicuous in planting his alibi in London on the day of the crime. The pamphleteer describes neither the binding over of the witnesses nor the conduct of the trial, save in one particular. The trial judge, Tanfield, "having perused their [the accuseds'] severall examinations [that is, the pretrial examinations transcribed by the JPs pursuant to the Marian committal statute], to avoyd all partiallity which consanguinity or acquantance might impose, his Lordshippe alter [ed] the whole body of the Grand Jury, which were for the most part of the Westerne parts of Summersetshire; and therefore in likely-hood of most knowne acquaintance unto Maister Smithwicke who sometimes had been a Grand Jury man himselfe." The grand jury indicted and the trial jury convicted Alice, the two bloodied men Baker and Austin, and Young Smithwicke. Once again, the JPs had built a successful prosecution case.

\section{Why the JPs?}

England must have been full of people who were not already burdened, in Lambarde's famous phrase, with the "Stacks of Statutes" $6: 3$ which the JPs had to administer and enforce. Granted that the prosecutorial office developed in response to the increasing passivity of the juries, why was it that the job came to be lodged with the JPs?

The prosecutorial function fitted easily into the JPs' established responsibilities in keeping the peace, especially their power to commit and to bail accused felons. Long before the Marian statutes the

63. Lambarde, op. cit. supra, note 43, p. 39. 
JPs had to assume investigatorial duties in order to exercise such powers wisely. In turn, as we have seen in the chap-book cases Dell and Sawyer, the investigatorial role tended to import the forensic. Evidence that informal practice among the JPs anticipated and probably suggested the Marian statutes puts the choice of the JPs in its proper light. They were so apt for the office that they appear to have evolved it on their own.

The institution of the prosecuting JP was neither the first nor the only solution. The expansion of the prerogative criminal process, both in the growth of the court of Star Chamber and in the frequent intervention of the Council in difficult criminal investigations, was symptomatic of the dissatisfaction with the ancient process; so, too, in a narrower sense, was the growth of process by information..$^{64}$ The extraordinary growth of statutory qui tam actions (rewarding private prosecutors with a share of the fine) is the most revealing of the crown's various experiments, because it shows the length to which the crown was willing to go to avoid the creation of an expensive, centrally-directed professional prosecutorial corps. The informer was thought of as a bearer of " $[p]$ ublic opinion and local knowledge," a figure who had theretofore been harnessed in presentment juries. Since it had become difficult to extract his information, he would be induced by "sufficient incentives" 65 to divulge it on his own motion. These bounty actions were never a serious alternative for the run of felonies. Such procedures were confined in the main to economic regulation, where it could be foreseen that the offender would be able to pay a fine. Soon enough the system revealed its capacity for being abused, and had itself to be regulated under Elizabeth. ${ }^{66}$ But the experiment does show in a related sphere the two themes which underlie the Marian solution for prosecuting felony by the justices of the peace. Prosecution should be local, to draw upon the knowledge of the community. And it should be cheap, costing the crown as little as possible. There was only one workable alternative to the prosecuting JPs, rewarded with honor and authority rather than money: professional prosecution by a centrally organized and paid prosecutorial corps. There is no evidence that the English gave it any thought. The tradition was otherwise, and neither the money nor the personnel were to hand.

64. See Holdsworth, op. cit. supra, note 11, v. 9, p. $236 \mathrm{ff}$.

65. Margaret G. Davies, The Enforcement of English Apprenticeship 1563-1642, p. 25 (1956).

66. Davies, op. cit. supra, note 65 , p. 63 , ff. 